九州大学学術情報リポジトリ

Kyushu University Institutional Repository

\title{
Increased Prostaglandin E_2 Has a Positive Correlation with Plasma Calcium during Goldfish Reproduction
}

Suzuki, Nobuo

Noto Marine Laboratory, Institute of Nature and Environmental Technology

Maruyama, Yusuke

Department of Biology, College of Liberal Arts and Sciences, Tokyo Medical and Dental University

Nakano, Masaki

Department of Biology, College of Liberal Arts and Sciences, Tokyo Medical and Dental University

Hattori, Atsuhiko

Department of Biology, College of Liberal Arts and Sciences, Tokyo Medical and Dental University

他

https://doi.org/10.5109/1434389

出版情報：九州大学大学院農学研究院紀要. 59 (1)，pp.97-101，2014-02-28. Faculty of Agriculture， Kyushu University

バージョン :

権利関係 : 


\title{
Increased Prostaglandin $\mathbf{E}_{2}$ Has a Positive Correlation with Plasma Calcium during Goldfish Reproduction
}

\section{Nobuo SUZUKI ${ }^{1 *}$, Yusuke MARUYAMA ${ }^{2}$, Masaki NAKANO ${ }^{2}$, Atsuhiko HATTORI ${ }^{2}$, Masato HONDA ${ }^{3}$, Yohei SHIMASAKI ${ }^{3}$, Toshio SEKIGUCHI ${ }^{1}$, Hiroyuki MISHIMA ${ }^{4}$, Shigehito WADA ${ }^{5}$, Ajai K. SRIVASTAV ${ }^{6}$, Kazuichi HAYAKAWA ${ }^{7}$ and Yuji OSHIMA $^{3}$}

\author{
Department of Bioscience and Biotechnology, Graduate School of Bioresource and \\ Bioenvironmental Sciences, Kyushu University, Hakozaki 6-10-1, \\ Higashi-ku, Fukuoka, 812-8581, Japan \\ (Received October 24, 2013 and accepted November 11, 2013)
}

\begin{abstract}
We recently demonstrated that prostaglandin $\mathrm{E}_{2}\left(\mathrm{PG}_{2}\right)$ increases osteoclastic activity and induces bone resorption in both in vitro and in vivo experiments using goldfish. In the fish reproductive period, the plasma calcium (Ca) level in female teleosts increases remarkably to make vitellogenin, which is a major component of egg protein and a Ca-binding protein. In this period, however, there is no reported relationship between $\mathrm{PGE}_{2}$ and Ca metabolism in fish. To clarify the Ca metabolism in fish reproduction, we examined plasma $\mathrm{PGE}_{2}$ and Ca levels and measured tartrate-resistant acid phosphatase (TRAP) activities as an indicator of osteoclastic activity in goldfish. Plasma $\mathrm{PGE}_{2}$ levels in the reproductive stage significantly increased as compared with those in non-reproductive stages. Also, both plasma Ca and TRAP increased in the reproductive stage. Significant positive correlations were recognized between plasma Ca and the gonad somatic index $(r=0.81, p<0.001)$, plasma Ca and plasma $\mathrm{PGE}_{2}$ levels $(r=0.635, p<0.05)$, and plasma Ca and plasma TRAP activities $(r=0.584, p<0.05)$ from the analysis using samples of both reproductive and nonreproductive stages. Taking these data into consideration, we suggested that $\mathrm{PGE}_{2}$ acts on osteoclasts and increases plasma $\mathrm{Ca}$ as a result of osteoclastic bone resorption, and we concluded that $\mathrm{PGE}_{2}$ is an important hormone in Ca metabolism during fish reproduction.
\end{abstract}

Key words: goldfish, plasma $\mathrm{Ca}$, Prostaglandin $\mathrm{E}_{2}$, reproduction, TRAP

\section{INTRODUCTION}

Prostaglandin $\mathrm{E}_{2}\left(\mathrm{PGE}_{2}\right)$ functions to bone metabolism and is an important hormone in bone and promoter of osteoclastogenesis (Kaji et al., 1996; Gardner, 2007; Kaneko et al., 2007). The bone-resorbing activity of mature osteoclasts in osteoblast-containing mouse bone cell cultures was increased by $\mathrm{PGE}_{2}$, although it did not affect osteoclast-like cell formation in osteoblast-free mouse spleen cell cultures (Kaji et al., 1996). Therefore, we focused on fish scales that coexist with both osteo-

Noto Marine Laboratory, Institute of Nature and Environmental Technology, Kanazawa University, Housu-gun, Ishikawa 9270553, Japan

2 Department of Biology, College of Liberal Arts and Sciences, Tokyo Medical and Dental University, Ichikawa, Chiba 2720827, Japan

${ }^{3}$ Department of Bioscience and Biotechnology, Graduate School of Bioresource and Bioenvironmental Sciences, Kyushu University, Hakozaki 6-10-1, Higashi-ku, Fukuoka, 812-8581, Japan

${ }^{4}$ Department of Medical Hygiene, Kochi Gakuen College, Kochi 780-0955, Japan

Department of Oral and Maxillofacial Surgery, Faculty of Medicine, University of Toyama, Sugitani, Toyama 930-0194, Japan

${ }^{6}$ Department of Zoology, D.D.U. Gorakhpur University, Gorakhpur 273009, India

Faculty of Pharmaceutical Sciences, Institute of Medical, Pharmaceutical and Health Sciences, Kanazawa University, Kanazawa, Ishikawa 920-1192, Japan

* Corresponding author (E-mail: nobuos@staff.kanazawa-u. ac.jp) clasts and osteoblasts (Bereiter-Hahn and Zylberberg, 1993; Suzuki et al., 2000; Yoshikubo et al., 2005; Suzuki et al., 2007; Suzuki et al., 2008; Suzuki et al., 2011; Yano et al., 2013). Using the goldfish scale in vitro assay system, we recently demonstrated that $\mathrm{PGE}_{2}$ acts on osteoblasts and then increases the osteoclastic activity in the scales of goldfish as it does in the bone of mammals (Omori et al., 2012). In addition, the intraperitoneal injection of $\mathrm{PGE}_{2}$ into goldfish induced hypercalcemia (Omori et al., 2012).

In the reproductive period, the plasma calcium (Ca) level in female teleosts increases remarkably (Watts et al., 1975; Yamauchi et al., 1978; Norberg et al., 1989; Suzuki et al., 2004). This Ca is bound to vitellogenin, which is a major component of egg protein and the calcium-binding protein (Tinsley, 1985; Kwon et al., 1993). In this period, $\mathrm{PGE}_{2}$ synthesized in the ovaries functions to cause ovulation in fish (for a review, see Takahashi et al., 2013). As van Anholt et al. (2003) reported that $\mathrm{PGE}_{2}$ in the blood may serve some physiological roles in fish, $\mathrm{PGE}_{2}$ secreted from the ovaries might influence plasma Ca in fish. However, there has been no reported relationship between $\mathrm{PGE}_{2}$ and Ca metabolism during the fish reproductive period.

To clarify the Ca metabolism in fish reproduction, we examined plasma $\mathrm{PGE}_{2}$ and Ca levels and measured tartrate-resistant acid phosphatase (TRAP) activities as an indicator of osteoclastic activity in goldfish.

We concluded that $\mathrm{PGE}_{2}$ is an important hormone in Ca metabolism during fish reproduction. 


\section{MATERIALS AND METHODS}

\section{Animals}

Female goldfish $(\mathrm{n}=14,49.16 \pm 3.77 \mathrm{~g})$ were purchased from a commercial source (Higashikawa Fish Farm, Yamatokoriyama, Japan) and used in the present study. All experimental procedures were conducted in accordance with the Guide for the Care and Use of Laboratory Animals of Kanazawa University.

\section{Measurement of plasma $\mathrm{PGE}_{2}, \mathrm{Ca}$, and TRAP levels of female goldfish in reproductive and non-repro- ductive stages}

Goldfish in both the reproductive (March) $(\mathrm{n}=8)$ and non-reproductive (August) $(n=6)$ stages were anesthetized with ethyl 3-aminobenzoate methanesulfonic acid salt (Sigma-Aldrich Inc., MO, USA). After weighing, the gonad somatic index (GSI) (\%) was calculated. A blood sample was then collected from the dorsal aorta using a heparinized syringe. After centrifugation at 15,000 rpm for $3 \mathrm{~mm}$, the plasma was immediately frozen and kept at $-80^{\circ} \mathrm{C}$ until use. The plasma total $\mathrm{Ca}(\mathrm{mg} / 100 \mathrm{ml})$ and $\mathrm{PGE}_{2}(\mathrm{pg} / \mathrm{ml})$ levels were determined using specific assay kits (Ca: Calcium E test; $\mathrm{PGE}_{2}$ : $\mathrm{PGE}_{2}-$ ELISA kit, Wako Pure Chemical Industries, Ltd., Osaka, Japan).

The plasma TRAP level was measured using $2 \mu \mathrm{l}$ of plasma from each goldfish. TRAP activities were measured using an acid tartrate buffer (a $20 \mathrm{mM}$ tartrate in a $0.1 \mathrm{M}$ sodium acetate buffer ( $\mathrm{pH} 5.3)$ ). An aliquot of $100 \mu \mathrm{l}$ of $20 \mathrm{mM}$ para-nitrophenyl phosphate in an acid tartrate buffer was added to each well in a 96-well microplate. This plate was then incubated at $20^{\circ} \mathrm{C}$ for $30 \mathrm{~min}$ while being shaken. After incubation, the reaction was stopped by adding $50 \mu \mathrm{l}$ of a $3 \mathrm{~N} \mathrm{NaOH}-20 \mathrm{mM}$ EDTA solution, and the absorbance was then measured at $405 \mathrm{~nm}$. The absorbance was converted into the amount of produced para-nitrophenol (pNP) using a standard curve for $\mathrm{pNP}$.

\section{Statistical analysis}

All results are expressed as the means $\pm \mathrm{SE}$. Statistical significance was assessed by Student's $t$-test. Simple correlation coefficients were calculated to assess the relationship among GSI values, plasma $\mathrm{PGE}_{2}$ levels, plasma Ca levels, and plasma TRAP activities. The statistical significance of the correlation was evaluated using the method of Snedecor and Cochran (1980). In all cases, the selected significance level was $p<0.05$.

\section{RESULTS}

Changes in GSI, plasma PGE, levels, Ca levels, and TRAP activities of female goldfish in reproductive and non-reproductive stages

There was a significant difference in the values of GSI between goldfish in March and August (Fig. 1). In addition, the plasma $\mathrm{PGE}_{2}$ levels, Ca levels, and TRAP activities of female goldfish in March were significantly higher than those in August (Figs. 2, 3, and 4).

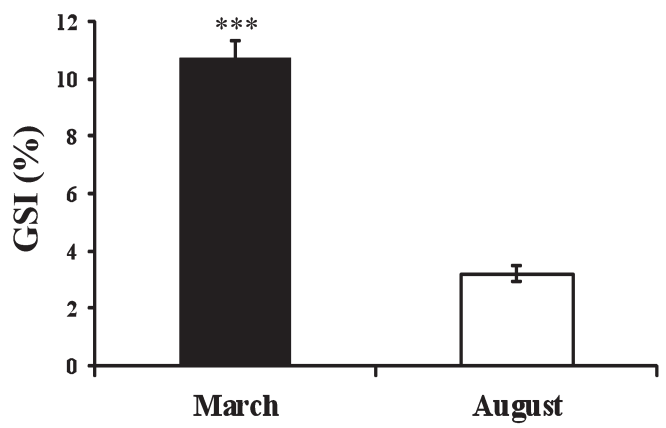

Fig. 1. GSI values of female goldfish in the reproductive (March) and non-reproductive (August) stages. *** indicates a statistically significant difference at $p<0.001$ in the values of the reproductive and nonreproductive stages.

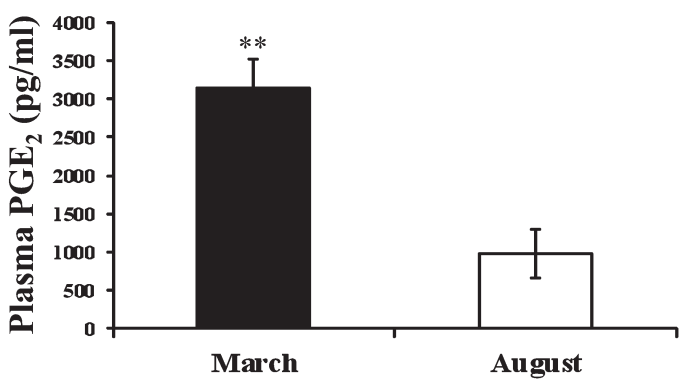

Fig. 2. Plasma $\mathrm{PGE}_{2}$ values of female goldfish in the reproductive (March) and non-reproductive (August) stages. $* *$ indicates a statistically significant difference at $p<0.01$ in the values of the reproductive and non-reproductive stages.

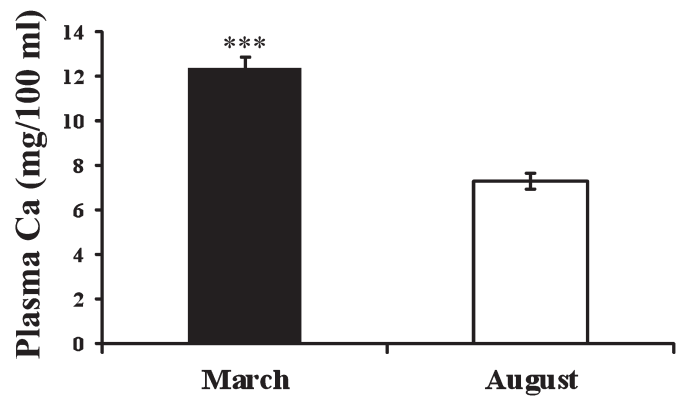

Fig. 3. Plasma Ca values of female goldfish in the reproductive (March) and non-reproductive (August) stages. *** indicates a statistically significant difference at $p<0.001$ in the values of the reproductive and nonreproductive stages.

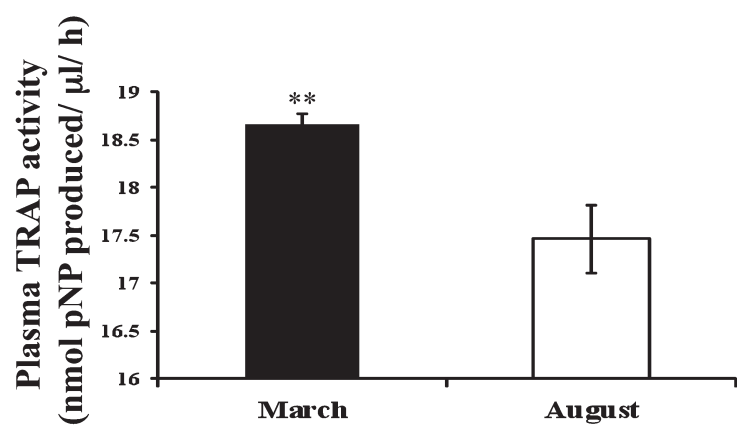

Fig. 4. Plasma TRAP activity (nmol pNP produced $/ \mu \mathrm{l} / \mathrm{h}$ ) values of female goldfish in the reproductive (March) and non-reproductive (August) stages. ** indicates a statistically significant difference at $p<0.01$ in the values of the reproductive and nonreproductive stages. 


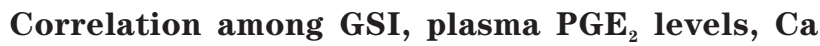
levels, and TRAP activities

The results of correlation among GSI, plasma $\mathrm{PGE}_{2}$ levels, Ca levels, and TRAP activities are indicated in Table 1. Significant positive correlations were recognized

Table 1. Correlation among GSI, plasma Ca levels, $\mathrm{PGE}_{2}$ levels, and TRAP activities $(\mathrm{n}=14)$.

\begin{tabular}{|c|c|c|}
\hline & $r$ values & $p$ values \\
\hline GSI vs Plasma $\mathrm{PGE}_{2}$ & $r=0.790$ & $p=0.0007$ \\
\hline GSI vs Plasma Ca & $r=0.813$ & $p=0.0004$ \\
\hline GSI vs Plasma TRAP & $r=0.631$ & $p=0.015$ \\
\hline Plasma Ca vs Plasma $\mathrm{PG}_{\mathrm{E} 2}$ & $r=0.635$ & $p=0.014$ \\
\hline Plasma Ca vs Plasma TRAP & $r=0.584$ & $p=0.028$ \\
\hline 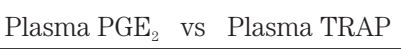 & $r=0.514$ & $p=0.058$ \\
\hline
\end{tabular}

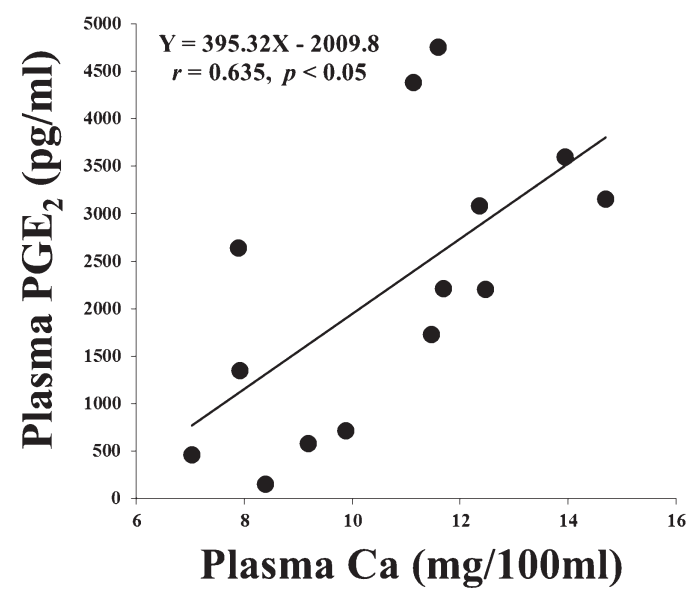

Fig. 5. Relationship between $\mathrm{PGE}_{2}(\mathrm{pg} / \mathrm{ml})$ and $\mathrm{Ca}$ (mg/100 ml) in the plasma of goldfish in the reproductive (March) and non-reproductive (August) stages.

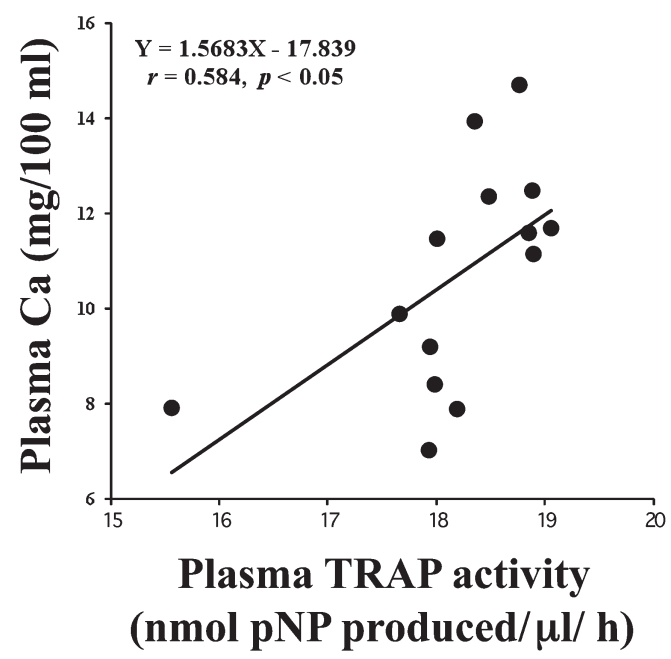

Fig. 6. Relationship between $\mathrm{Ca}(\mathrm{mg} / 100 \mathrm{ml})$ and TRAP activities (nmol pNP produced $/ \mu \mathrm{l} / \mathrm{h}$ ) in the plasma of goldfish in the reproductive (March) and nonreproductive (August) stages. between GSI and plasma $\mathrm{PGE}_{2}(r=0.790, p<0.001)$, GSI and plasma $\mathrm{Ca}(r=0.813, p<0.001)$, and GSI and plasma TRAP $(r=0.631, p<0.05)$ from the analysis using samples of both reproductive and non-reproductive stages.

As a result of having paid attention to the relations with plasma $\mathrm{Ca}$, we discovered a significant positive relationship between plasma $\mathrm{Ca}$ and $\mathrm{PGE}_{2}(r=0.635, p<0.05)$ (Fig. 5), and between plasma $\mathrm{Ca}$ and TRAP $(r=0.584$, $p<0.05$ ) (Fig. 6).

As $\mathrm{PGE}_{2}$ levels increased, plasma TRAP activities tended to rise $(r=0.514, p=0.058)$.

\section{DISCUSSION}

The present study is the first to demonstrate that $\mathrm{PGE}_{2}$ is related to $\mathrm{Ca}$ metabolism in fish reproduction.

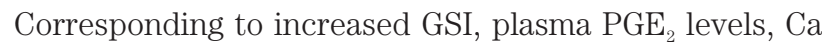
levels, and TRAP activities rose. In addition, significant correlations between plasma $\mathrm{Ca}$ and $\mathrm{PGE}_{2}$ and between Ca and TRAP were observed. Because TRAP is known as an osteoclast-specific marker (for a review, see Vaes, 1988), the increased $\mathrm{PGE}_{2}$ in the March fish activated osteoclasts and promoted osteoclastic bone resorption. As described in the introduction, we recently demonstrated that $\mathrm{PGE}_{2}$ acts on osteoblasts and increases the osteoclastic activity in the scales of goldfish as it does in the bone of mammals (Omori et al., 2012). In an in vivo experiment, furthermore, hypercalcemia was induced as a result of osteoclastic bone resorption after an intraperitoneal injection of $\mathrm{PGE}_{2}$ into goldfish (Omori et al., 2012). Taking these results into consideration together with the present study, we have concluded that $\mathrm{PGE}_{2}$ acts as a calcemic hormone in fish reproduction.

In the present study, the highest correlation between GSI and plasma Ca was recognized. We think that several hormones, with the exception of $\mathrm{PGE}_{2}$, are involved in Ca metabolism during fish reproduction. The candidate for this hypercalcemic hormone is estrogen. In female teleosts, estrogen enhances the synthesis of vitellogenin, which is a major component of egg protein and a Ca-binding protein (Tinsley, 1985; Kwon et al., 1993). At the same time, estrogen promotes Ca resorption from the scales by activating osteoclasts (Persson et al., 1995; Suzuki et al., 2000; Suzuki and Hattori, 2003; Suzuki et al., 2009). Consequently, plasma vitellogenin and Ca levels increase corresponding to the increase in estrogen level (Norberg et al., 1989). $\mathrm{PGE}_{2}$ is closely related to ovulation (late stage of fish reproduction) (for a review, see Takahashi et al., 2013), suggesting that in the early stage of fish reproduction, estrogen acts as a hypercalcemic hormone, and then $\mathrm{PGE}_{2}$ plays roles in both ovulation and Ca metabolism.

On the other hand, we previously demonstrated that a hypocalcemic hormone, calcitonin, acts on scales and inhibits osteoclastic activity using an in vitro scale assay system with goldfish (Suzuki et al., 2000). As estrogen activates osteoclasts in some teleosts in both in vivo and in vitro experiments (Persson et al., 1995; Suzuki et al., 2000; Suzuki and Hattori, 2002; Suzuki and Hattori, 2003; Suzuki et al., 2009), a counteraction may 
exist between calcitonin and estrogen in osteoclasts of the scale. Using the in vitro scale assay system, the increased osteoclastic activity with estrogen was actually suppressed by calcitonin in goldfish (Suzuki et al., 2000). Furthermore, our previous study demonstrated the interaction between calcitonin and estrogen. In the ultimobranchial gland, which is the secretion organ of calcitonin, estrogen receptors were detected by estrogenspecific binding assay and immunohistochemical analysis in goldfish (Suzuki et al., 2004). Also, three types of estrogen receptors were detected in the ultimobranchial gland of goldfish (Suzuki et al., 2004). Moreover, just after injecting estrogen into goldfish, plasma calcitonin level increased before the rise of plasma Ca (Suzuki et al., 2004). Considering from our present data, we strongly suggested that $\mathrm{PGE}_{2}$ affects other calcemic hormones in fish reproduction. Thus, in the future, we will examine the interaction among calcemic hormones, such as $\mathrm{PGE}_{2}$, calcitonin, and estrogen, and elucidate the mechanism of teleost bone metabolism during the reproductive stages.

\section{ACKNOWLEDGMENTS}

This study was supported in part by grants to N.S. (Grant-in-Aid for Scientific Research [C] No. 24620004 by JSPS), to A.H. (Grant-in-Aid for Scientific Research [C] No. 24570068 by JSPS), to T. S. (Grant-in-Aid for Young Scientists [B] No. 40378568 by JSPS), to H.M. (Grant-in-Aid for Scientific Research [C] No. 23592727 by JSPS), and to K.H. (Grant-in-Aid for Scientific Research for Exploratory Research No.24651044 by JSPS).

\section{REFERENCES}

Bereiter-Hahn, J. and L. Zylberberg 1993 Regeneration of teleost fish scale. Comp. Biochem. Physiol., 105A: 625-641

Gardner, C. R. 2007 Comparison of morphological effects of $\mathrm{PGE}_{2}$ and TGF $\beta$ on osteoclastogenesis induced by RANKL in mouse bone marrow cell cultures. Cell Tissue Res., 330: 111-121

Kaji, H., T. Sugimoto, M. Kanatani, M. Fukase, M. Kumegawa and K. Chihara 1996 Prostaglandin $\mathrm{E}_{2}$ stimulates osteoclast-like cell formation and bone-resorbing activity via osteoblasts: Role of cAMP-dependent protein kinase. J. Bone Mineral Res., 11: $62-71$

Kaneko, H., M. Mehrotra, C. Alander, U. Lerner, C. Pilbeam and L. Raisz 2007 Effects of prostaglandin $\mathrm{E}_{2}$ and lipopolysaccharide on osteoclastogenesis in RAW 264.7 cells. Prostaglandins Leukot. Essent. Fatty Acids, 77: 181-186

Kwon, H.C., S. Hayashi and Y. Mugiya 1993 Vitellogenin induction by estradiol-17 $\beta$ in primary hepatocyte culture in the rainbow trout, Oncorhynchus mykiss. Comp. Biochem. Physiol., 104B: $381-386$

Norberg B, B. Th. Björnsson, C. L. Brown, U.-P. Wichardt, L. J. Deftos and C. Haux 1989 Changes in plasma vitellogenin, sex steroids, calcitonin, and thyroid hormones related to sexual maturation in female brown trout (Salmo trutta). Gen. Comp. Endocrinol., 75: 316-326

Omori, K., S. Wada, Y. Maruyama, A. Hattori, K. Kitamura, Y. Sato, M. Nara, H. Funahashi, K. Yachiguchi, K. Hayakawa, M. Endo,
R. Kusakari, S. Yano, A.K. Srivastav, T. Kusui, S. Ejiri, W. Chen, Y. Tabuchi, Y. Furusawa, T. Kondo, Y. Sasayama, T. Nishiuchi, M. Nakano, T. Sakamoto and N. Suzuki 2012 Prostaglandin $\mathrm{E}_{2}$ increases both osteoblastic and osteoclastic activity in the scales and participates in calcium metabolism in goldfish. Zool. Sci., 29: 499-504

Persson, P., Y. Takagi and B. T. Björnsson 1995 Tartrate resistant acid phosphatase as a marker for scale resorption in rainbow trout, Oncorhynchus mykiss: Effects of estradiol-17 $\beta$ treatment and refeeding. Fish Physiol. Biochem., 14: 329-339

Snedecor, G. W. and W. G. Cochran 1980 Statistical Methods, seventh ed. Iowa State Univ. Press, Ames (USA)

Suzuki, N., J. A. Danks, Y. Maruyama, M. Ikegame, Y. Sasayama, A. Hattori, M. Nakamura, M.J. Tabata, T. Yamamoto, R. Furuya, K. Saijoh, H. Mishima, A. K. Srivastav, Y. Furusawa, T. Kondo, Y. Tabuchi, I. Takasaki, V.S. Chowdhury, K. Hayakawa and T.J. Martin 2011 Parathyroid hormone 1 (1-34) acts on the scales and involves calcium metabolism in goldfish. Bone, 48: $1186-$ 1193

Suzuki, N. and A. Hattori 2002 Melatonin suppresses osteoclastic and osteoblastic activities in the scales of goldfish. J. Pineal Res., 33: 253-258

Suzuki, N. and A. Hattori 2003 Bisphenol A suppresses osteoclastic and osteoblastic activities in the cultured scales of goldfish. Life Sci., 73: 2237-2247

Suzuki, N., K. Hayakawa, T. Kameda, A. Toriba, N. Tang, M.J. Tabata, K. Takada, S. Wada, K. Omori, A.K. Srivastav, H. Mishima and A. Hattori 2009 Monohydroxylated polycyclic aromatic hydrocarbons inhibit both osteoclastic and osteoblastic activities in teleost scales. Life Sci., 84: 482-488

Suzuki, N., K. Kitamura, T. Nemoto, N. Shimizu, S. Wada, T. Kondo, M. J. Tabata, F. Sodeyama, K. Ijiri and A. Hattori 2007 Effect of vibration on osteoblastic and osteoclastic activities: Analysis of bone metabolism using goldfish scale as a model for bone. Adv. Space Res., 40: 1711-1721

Suzuki, N., M. Somei, A. Seki, R.J. Reiter and A. Hattori 2008 Novel bromomelatonin derivatives as potentially effective drugs to treat bone diseases. J. Pineal Res., 45: 229-234

Suzuki, N., T. Suzuki and T. Kurokawa 2000 Suppression of osteoclastic activities by calcitonin in the scales of goldfish (freshwater teleost) and nibbler fish (seawater teleost). Peptides, 21: $115-124$

Suzuki, N., K. Yamamoto, Y. Sasayama, T. Suzuki, T. Kurokawa, A. Kambegawa, A. K. Srivastav, S. Hayashi and S. Kikuyama 2004 Possible direct induction by estrogen of calcitonin secretion from ultimobranchial cells in the goldfish. Gen. Comp. Endocrinol., 138: 121-127

Takahashi, T., C. Fujimori, A. Hagiwara, and K. Ogiwara 2013 Recent advances in the understanding of teleost medaka ovulation: The roles of proteases and prostaglandins. Zool. Sci., 30: $239-247$

Tinsley, D. 1985 A comparison of plasma levels of phosphoprotein, total protein and total calcium as indirect indices of exogenous vitellogenesis in the Crucian carp, Carassius carassius (L.). Comp. Biochem. Physiol., 80B: 913-916

Vaes, G. 1988 Cellular biology and biochemical mechanism of bone resorption. Clin. Orthop. Relat. Res., 231: 239-271

van Anholt, R. D., T. Spanings, W. Koven and S. E. Wendelaar Bonga 2003 Effects of acetylsalicylic acid treatment on thyroid hormones, prolactins, and the stress response of tilapia 
(Oreochromis mossambicus). Am. J. Physiol. Regul. Integr. Comp. Physiol., 285: R1098-R1106

Watts, E. G., D. H. Copp and L. J. Deftos 1975 Changes in plasma calcitonin and calcium during the migration of salmon. Endocrinology, 96: 214-218

Yamauchi, H., H. Orimo, K. Yamauchi, K. Takano and H. Takahashi 1978 Increased calcitonin levels during ovarian development in the eel, Anguilla japonica. Gen. Comp. Endocrinol., 36: 526-529

Yano, S., K. Kitamura, Y. Satoh, M. Nakano, A. Hattori, T. Sekiguchi,
M. Ikegame, H. Nakashima, K. Omori, K. Hayakawa, A. Chiba, Y. Sasayama, S. Ejiri, Y. Mikuni-Takagaki, H. Mishima, H. Funahashi, T. Sakamoto and N. Suzuki 2013 Static and dynamic hypergravity responses of osteoblasts and osteoclasts in medaka scales. Zool. Sci., 30: 217-223

Yoshikubo, H., N. Suzuki, K. Takemura, M. Hoso, S. Yashima, S. Iwamuro, Y. Takagi, M. J. Tabata and A. Hattori 2005 Osteoblastic activity and estrogenic response in the regenerating scale of goldfish, a good model of osteogenesis. Life Sci., 76: $2699-2709$ 